\title{
ОЦІНКА ПОТЕНЦІАЛУ ВПРОВАДЖЕННЯ ДУАЛЬНОЇ СИСТЕМИ НАВЧАННЯ В УКРАЇНI
}

\author{
Ярослава Левченко \\ доктор філософії з галузі «Соціальні і поведінкові науки», доцент, \\ доцент кафедри економіки і підприємництва, \\ Харківський національний автомобільно-дорожній університет, \\ м. Харків, Україна \\ ORCID ID 0000-0002-4979-1101 \\ slavalevcenko1984@gmail.com \\ Олена Шершенюк \\ кандидат економічних наук, доцент, \\ доцент кафедри економіки і підприємництва, \\ Харківський національний автомобільно-дорожній університет, \\ м. Харків, Україна \\ ORCID ID 0000-0002-9959-2725 \\ sheralyona@gmail.com
}

\begin{abstract}
Анотація. У статті проведено оцінку потенціалу впровадження дуальної системи навчання в Україні, що є метою дослідження. Для досягнення окресленої мети були вирішені такі задачі: визначено фактори впливу на впровадження дуального навчання та їхні показники; на основі побудови матриці кореляційних зв'язків, визначені кореляційні взаємовпливи між показниками факторів впливу впровадження дуального навчання.

Результати розрахунків зафіксували динаміку до зростання. Це свідчить про зростання потенціалу впровадження дуального освіти в Україні. Визначено фактори впливу на впровадження дуального навчання, а саме: економічні, політичні та культурно-освітні. Також були окреслені кореляційні взаємовпливи між показниками факторів впливу впровадження дуального навчання. Визначені як тісні позитивні, так і тісні негативні взаємовпливи.

Ключові слова: якість освіти, дуальна система навчання, потенціал впровадження дуального навчання, кореляційні взаємовпливу, фактори і показники впливу.
\end{abstract}

Постановка проблеми. Основою успішного економічного розвитку країни є якість і система освіти. У результаті стрімких економічних перетворень, появи нових технологій, зміни самої парадигми індустріального розвитку можна спостерігати деяке ослаблення зв'язку між державними навчальними закладами та ринком праці. Та й проблема не лише в цьому. У 2019 році було проведено комплексне дослідження (Левченко, Волинец, 2019), де охарактеризовано основні негативні сторони очима студента, які безпосередньо впливають на якість освіти. Серед таких можна відзначити:

- непривабливість наявних методів проведення занять у тій формі, яка використовується викладачами зараз;

(ㄷ ДВНЗ «Донбаський державний педагогічний університет» 
- неможливість суміщення навчання та практичного застосування навичок.

3 представленої інформації цього дослідження стає зрозуміло, чому запит на дистанційне навчання значно вище, ніж є насправді. Тільки $40 \%$ респондентів відвідують заняття в середньому на $81-100 \%$. Решта 60\% відвідують заняття набагато рідше. Так, 25\% студентів відвідують заняття в середньому на $61-80 \%$, ще $25 \%$ учнів відвідують заняття в середньому на $41-60 \%$, а решта $10 \%$ - на 21 - 40\%. І це ні в якій мірі не говорить про те, що студенти нині стали більш ліниві або байдужі. Усі вони зайняті різного роду діяльністю. Стипендії не задовольняють їхні потреби, і вони змушені працювати (Левченко, Волинец, 2019).

Актуальність піднятої проблеми підтверджується також курсом України в європейський простір. Політичне спрямування іiі розвитку обумовлено ратифікацією 16 вересня 2014 Верховною Радою України і Свропейським парламентом Угоди про асоціацію між Україною та Європейським союзом (СС). Принципи угоди передбачають поступову економічну інтеграцію України з СС. Наслідком економічної інтеграції $\epsilon$ процес підвищення стандартів української продукції і послуг до європейського рівня. Оновлення виробничих і бізнес процесів, основних фондів підприємств вимагатиме фінансових інвестицій. А успіх економічних перетворень залежить від багатьох факторів.

Як відомо, основним капіталом у будь-якій компанії $є$ людський. Серед комплексу аспектів інвестування варто відзначити, що найбільш успішні та інноваційні компанії інвестують в людський капітал, зокрема у вирощування власних кадрів (Lechachenko, 2019; Левченко, Шершенюк, 2020). Тому питання про нагальність і своєчасність упровадження дуального навчання постає особливо гостро.

Аналіз останніх досліджень і публікацій. Термін «дуальна система» був уведений у педагогічну термінологію в середині 60 -х років минулого століття в Німеччині. Дуальність, як методологічна характеристика професійної освіти, передбачає узгоджену взаємодію освітньої та виробничої сфери з підготовки кваліфікованих кадрів певного профілю в межах організаційно різних форм навчання (Дуальна освіта, б.д.).

Наразі в Німеччині трохи більше половини абітурієнтів $(51,7 \%)$ вибирають дуальне навчання. Середня зарплата під час такого навчання становить 876 євро на місяць. Ї̈̈ платить підприємство. Триває навчання від двох до трьох із половиною років. 70\% навчальних годин студент проводить на виробництві, 30\% - у навчальному закладі. Після отримання дуальної освіти шукають роботу лише 4\% випускників. Для порівняння: серед тих, хто проходить навчання без реальної практики, відразу працевлаштуватися не може кожен п'ятий (19\%). 20\%

Професіоналізм педагога: теоретичні й методичні аспекти. - Вип. 12. - Слов'янськ, 2020. 
німецьких підприємств беруть участь у дуальному навчанні. Переважно це малі і середні підприємства, які інвестують близько 18 тис. євро на рік на кожного учня (більшість цієї суми йде на його зарплату). Але завдяки роботі учня $70 \%$ інвестицій повертаються ще під час навчання.

Держава бере участь у витратах бізнесу на дуальну освіту. Сума досягає 7 млрд. євро на рік. Що це дає країні? Німецькі малі і середні підприємства конкурентні на світовому ринку. Молодіжне безробіття становить лише 7,2\%. В Україні ж рівень безробіття серед молодих людей у віці до 24 років, за даними Державної служби статистики, становить 17,1\% (дані за 2018 г.) (Дуальна освіта - партнерство вишів і бізнесу, б.д.).

Досвід Німеччини вже повторили Канада, Австрія, Швейцарія і багато інших розвинених країн. Там близько половини всіх студентів користується саме такою формою навчання. У Великобританії у 2020 році на підприємствах планують створити три мільйони робочих місць на підтримку дуальної програми навчання. У Лондоні вирахували, що це дуже вигідно: кожен вкладений у студента фунт стерлінгів обертається прибутком у 18 фунтів (Вчитися на роботі: як працюватиме дуальна освіта в Україні, б.д.).

Що ж стосується України, то наразі є невеликий досвід упровадження дуальної форми навчання. Так відбувся перший випуск трьох експериментальних груп, який показав позитивні результати впровадження елементів дуальної форми навчання, а саме: високий рівень працевлаштування до 97\%, підвищення якості професійної підготовки - на 12 - 17\%, додаткові фінансові надходження - до 50000 гривень у кожному ПТУ, зменшення витрат на комунальні послуги та витратні матеріали, більш стійке і взаємовигідне співробітництво з роботодавцями.

Широкого поширення в Україні цієї практики немає. Так може Україна не має достатнього потенціалу впровадження дуального навчання? Відповідь на це питання буде надано в межах окресленого дослідження.

Формулювання цілей статті (постановка завдання). Метою цього дослідження є оцінка потенціалу впровадження дуальної системи навчання в Україні. Для досягнення визначеної мети були поставлені такі задачі:

- визначити чинники впливу на впровадження дуального навчання та їхні показники;

- визначити кореляційні взаємовпливи між показниками факторів впливу провадження дуального навчання на основі побудови матриці кореляційних в'язків.

Результати дослідження. На підставі запропонованої методики визначення потенціалу дуальної освіти (Lechachenko, 2019) і вдосконаленого 
підходу (Левченко, 2020) можна приступити до розрахунків. Уся необхідна інформація взята $з$ баз даних загального доступу (Офіційний сайт Державної служби статистики України, б.д.; Official site of Eurostat, n.d.; Official site of Organisation for Economic Cooperation and Development OECD, n.d.; BDO international business compass, 2018; PayingTaxes 2018 PwC Global, 2018; Schwab, 2018; Transparency International, Corruption perception index, 2018). Узагальнену статистичну інформацію представлено в табл. 1.

Таблиця 1

Зведена таблиця вхідних показників моделі оцінки потенціалу в динаміці 2014-2018 років

\begin{tabular}{|c|c|c|c|c|c|}
\hline Вхідні показники & 2014 & 2015 & 2016 & 2017 & 2018 \\
\hline \multicolumn{6}{|c|}{ Економічна модель } \\
\hline Рівень інвестиційної привабливості & 41,93 & 47,6 & 47,1 & 46,17 & 45,27 \\
\hline $\begin{array}{l}\text { Середній рівень зарплат в професійному } \\
\text { секторі }\end{array}$ & 3340 & 2064 & 2340 & 3024 & 3816 \\
\hline Рівень безробіття серед молоді & 23,1 & 22,4 & 23 & 17,8 & 17,9 \\
\hline Рівень зайнятості молоді & 21,39 & 22,06 & 21,48 & 27,9 & 27,6 \\
\hline Податкове навантаження на підприємства & 76,72 & 72,98 & 72,83 & 74,85 & 80,77 \\
\hline Рівень тіньового ринку праці & 27,87 & 27,03 & 27,75 & 21,45 & 21,6 \\
\hline Рівень конкуренції в країні & 53,9 & 49,4 & 49,8 & 49,4 & 45,6 \\
\hline \multicolumn{6}{|c|}{ Політична модель } \\
\hline Частка витрат ВВП на освіту & 6 & 5,4 & 5,72 & 5,3 & 6,7 \\
\hline Рівень впливу профспілок & 23 & 25 & 29 & 27 & 30 \\
\hline Рівень впливу організацій роботодавців & 45 & 46 & 57 & 53 & 60 \\
\hline Рівень корупції & 37,87 & 34,6 & 34,93 & 34,67 & 32 \\
\hline Рівень плинності кадрів & 17 & 18 & 16 & 19 & 23 \\
\hline \multicolumn{6}{|c|}{ Культурно-освітня модель } \\
\hline Престиж професійної освіти & 32 & 28,8 & 30,5 & 28,2 & 35,7 \\
\hline $\begin{array}{l}\text { Рівень інвестицій компаній в навчання } \\
\text { персоналу }\end{array}$ & 0,7 & 1 & 1,5 & 1,9 & 2,8 \\
\hline Автономія навчальних закладів & 45 & 47 & 50 & 50 & 55 \\
\hline
\end{tabular}

Почнемо 3 методу аналізу: визначення кореляційних взаємовпливів між показниками на основі побудови матриці кореляційних зв'язків.

На першому етапі на основі перевірки значень коефіцієнта лінійної кореляції значимості проводиться побудова кореляційних матриць у EXCEL, a потім повинна бути проведена очистка матриці.

Перевірка значень коефіцієнта значущості лінійної кореляції. Для цього слід оцінити критичне значення критерію. Оскільки для кожної вибірки було отримано по 5 значень (п'ять років), ступінь свободи становить $\mathrm{f}=5-2.3$ огляду на це, для $\alpha=0,05$ значення $\mathrm{t}=3,182$. Тоді з рівняння в EXCEL, яке виглядає так:

$$
t_{k}^{0,025,3}=\frac{3,182}{\sqrt{5-2+3,182^{2}}}=0,8783
$$

Професіоналізм педагога: теоретичні й методичні аспекти. - Вип. 12. - Слов'янськ, 2020. 
проводяться розрахунки.

Так, усі значення в кореляційній таблиці, значення яких по модулю менше 0,8783, можна вважати статистично незначущими та їхні значення в таблиці слід замінити нулем.

Мінливість досліджуваних показників визначається за допомогою коефіцієнта варіації. Коефіцієнт варіації застосовується тоді, коли необхідно порівняти мінливість ознак об'єкта, які виражені в різних одиницях виміру:

$$
K_{V A R}=\frac{\sigma(x)}{\bar{x}} \cdot 100 \%,
$$

де $\sigma(x)$ - середнє відхилення;

$x$ - середнє значення показника.

Мінливість вважається слабкою, якщо $v<10 \%$; якщо $v$ від 11-25\% середньої і значної, якщо $v>25 \%$.

\section{Економічна модель}

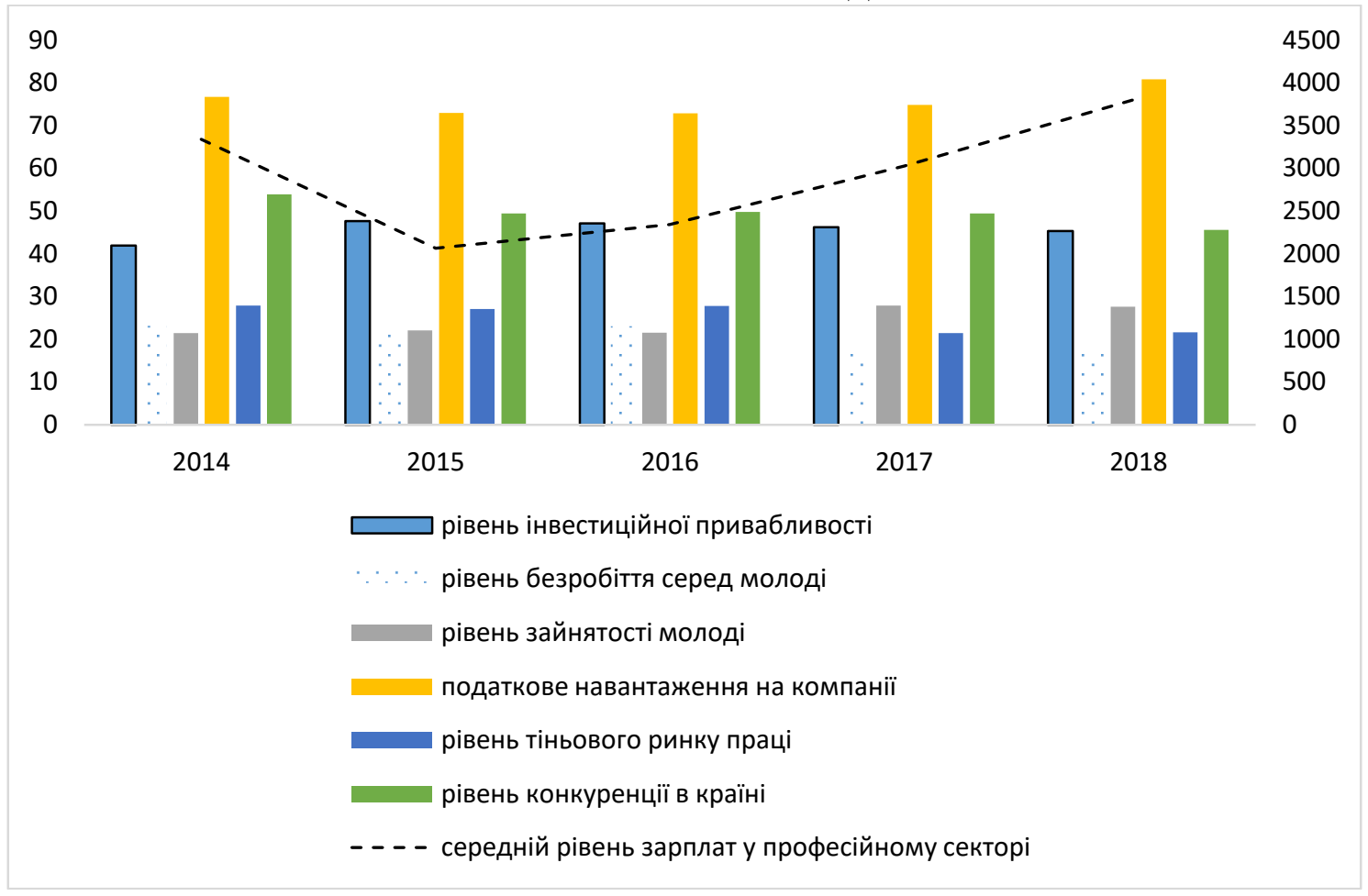

Рис.1. Динаміка показників економічної моделі

На основі отриманих даних будується матриця кореляцій (табл. 2).

Таблиця 2

Матриця кореляцій економічної моделі

\begin{tabular}{|c|c|c|c|c|c|c|c|}
\hline Показники & $\mathrm{X} 1$ & $\mathrm{X} 2$ & $\mathrm{X} 3$ & $\mathrm{X} 4$ & $\mathrm{X} 5$ & $\mathrm{X} 6$ & $\mathrm{X} 7$ \\
\hline $\mathrm{X} 1$ & 1 & & & & & & \\
\hline
\end{tabular}


Оцінка потенціалу впровадження дуальної системи навчання в Україні

\begin{tabular}{|c|c|c|c|c|c|c|c|}
\hline $\mathrm{X} 2$ & $-0,6768$ & 1 & & & & & \\
\hline $\mathrm{X} 3$ & $-0,1095$ & $-0,5830$ & 1 & & & & \\
\hline $\mathrm{X} 4$ & 0,0978 & 0,5875 & $-0,9996$ & 1 & & & \\
\hline $\mathrm{X} 5$ & $-0,5309$ & 0,9423 & $-0,5682$ & 0,5632 & 1 & & \\
\hline $\mathrm{X} 6$ & $-0,1095$ & $-0,5822$ & 1,0000 & $-0,9997$ & $-0,5665$ & 1 & \\
\hline $\mathrm{X} 7$ & $-0,5557$ & $-0,2065$ & 0,6881 & $-0,6718$ & $-0,4078$ & 0,6864 & 1 \\
\hline
\end{tabular}

Для більшої зручності роботи з матрицею наступним кроком проводиться іiі очищення.

Таблиця 3

Очищена матриця кореляцій економічної моделі
\begin{tabular}{|c|c|c|c|c|c|c|c|}
\hline Показники & $\mathrm{X} 1$ & $\mathrm{X} 2$ & $\mathrm{X} 3$ & $\mathrm{X} 4$ & $\mathrm{X} 5$ & $\mathrm{X} 6$ & $\mathrm{X} 7$ \\
\hline $\mathrm{X} 1$ & 1 & & & & & & \\
\hline $\mathrm{X} 2$ & 0 & 1 & & & & & \\
\hline $\mathrm{X} 3$ & 0 & 0 & 1 & & & & \\
\hline $\mathrm{X} 4$ & 0 & 0 & $-0,9996$ & 1 & & & \\
\hline $\mathrm{X} 5$ & 0 & 0,9423 & 0 & 0 & 1 & & \\
\hline $\mathrm{X} 6$ & 0 & 0 & 1 & $-0,9997$ & & 1 & \\
\hline $\mathrm{X} 7$ & 0 & 0 & 0 & 0 & 0 & 0 & 1 \\
\hline
\end{tabular}

У цьому випадку на нулі замінюються всі значення в кореляційній таблиці, величина яких по модулю менша 0,8783 , тобто ті, які вважаються статистично незначимі.

Є щільний позитивний зв'язок між податковим навантаженням на компанію і середнім рівнем зарплат у професійному секторі. Отже, зростання величини одного показника позитивно відбивається на іншому.

Є щільний негативний зв'язок між рівнем зайнятості молоді та рівнем безробіття серед молоді. Рівень тіньового ринку праці і рівень зайнятості молоді також корелюються обернено. Отже, зниження одного показника сприяє збільшенню іншого.

Далі перевіримо показники на мінливість і представимо результати в табл. 4.

Таблиця 4

Мінливість показників економічної моделі

\begin{tabular}{|l|c|c|c|c|c|c|c|}
\hline & $\mathrm{X} 1$ & $\mathrm{X} 2$ & $\mathrm{X} 3$ & $\mathrm{X} 4$ & $\mathrm{X} 5$ & $\mathrm{X} 6$ & $\mathrm{X} 7$ \\
\hline Коефіцієнт варіації & $4,40 \%$ & $22,00 \%$ & $11,77 \%$ & $12,46 \%$ & $3,88 \%$ & $11,80 \%$ & $5,30 \%$ \\
\hline
\end{tabular}

За результатами розрахунків спостерігається слабка мінливість за показниками: рівень інвестиційної привабливості, податкове навантаження на підприємства, рівень корупції в країні. Іншим показникам притаманна середня мінливість.

Професіоналізм педагога: теоретичні й методичні аспекти. - Вип. 12. - Слов'янськ, 2020. 


\section{Політична модель}

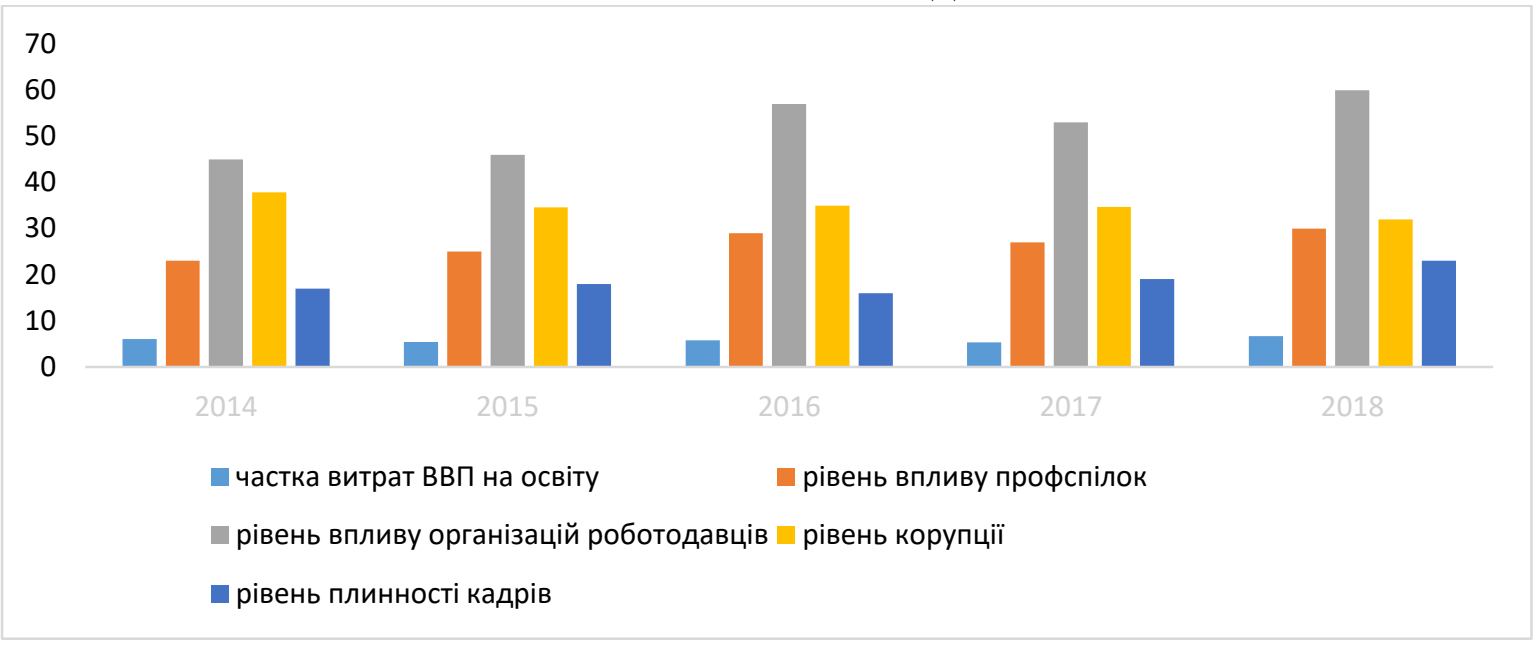

Рис. 2 . Динаміка показників політичної моделі

На основі отриманих вихідних даних будується матриця кореляцій політичної моделі.

Таблиця 5

Матриця кореляцій політичної моделі

\begin{tabular}{|c|c|c|c|c|c|}
\hline Показники & $\mathrm{X} 8$ & $\mathrm{X} 9$ & $\mathrm{X} 10$ & $\mathrm{X} 11$ & $\mathrm{X} 12$ \\
\hline $\mathrm{X} 8$ & 1 & & & & \\
\hline $\mathrm{X} 9$ & 0,3983 & 1 & & & \\
\hline $\mathrm{X} 10$ & 0,4896 & 0,9799 & 1 & & \\
\hline $\mathrm{X} 11$ & $-0,3788$ & $-0,8389$ & $-0,7663$ & 1 & \\
\hline & 0,6401 & 0,5041 & 0,5235 & $-0,7779$ & 1 \\
\hline
\end{tabular}

Для більшої зручності роботи з матрицею наступним кроком проводиться іiі очищення.

Таблиця 6

Очищена матриця кореляцій політичної моделі

\begin{tabular}{|c|c|c|c|c|c|}
\hline Показники & $\mathrm{X} 8$ & $\mathrm{X} 9$ & $\mathrm{X} 10$ & $\mathrm{X} 11$ & $\mathrm{X} 12$ \\
\hline $\mathrm{X} 8$ & 1 & & & & \\
\hline $\mathrm{X} 9$ & 0 & 1 & & & \\
\hline $\mathrm{X} 10$ & 0 & 0,9799 & 1 & & \\
\hline $\mathrm{X} 12$ & 0 & 0 & 0 & 1 & \\
\hline
\end{tabular}

Є щільний позитивний зв'язок між рівнем впливу організацій роботодавців i рівнем впливу профспілок. Отже, зростання величини одного показника позитивно позначається на іншому. 
Далі перевіримо показники на мінливість і представимо результати в табл. 7.

Мінливість показників політичної моделі

Таблиця 7

\begin{tabular}{|l|c|c|c|c|c|}
\hline & $\mathrm{X} 8$ & $\mathrm{X} 9$ & $\mathrm{X} 10$ & $\mathrm{X} 11$ & $\mathrm{X} 12$ \\
\hline Коефіціснт варіації & $9,65 \%$ & $10,68 \%$ & $12,66 \%$ & $5,98 \%$ & $14,53 \%$ \\
\hline
\end{tabular}

Слабка мінливість властива показником частка витрат ВВП на освіту i рівень корупції. Іншим показникам притаманна середня мінливість.

\section{Культурно-освітня модель}

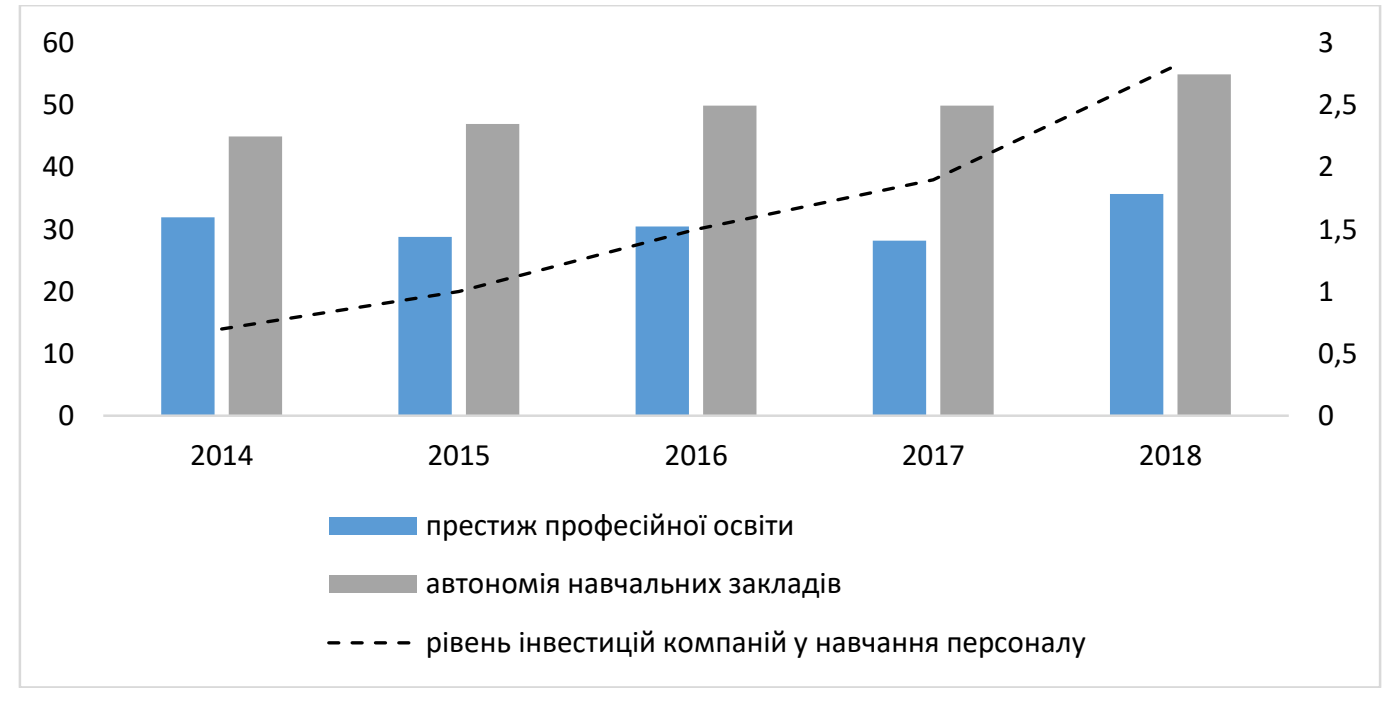

Рис.3. Динаміка показників культурно-освітньої моделі

На основі отриманих вихідних даних будується матриця кореляцій культурно-освітньої моделі.

Таблиця 8

Матриця кореляцій культурно-освітньої моделі

\begin{tabular}{|c|c|c|c|}
\hline Показники & X13 & X14 & X15 \\
\hline X13 & 1 & & \\
\hline X14 15 & 0,5341 & 1 & \\
\hline
\end{tabular}

Для більшої зручності роботи з матрицею наступним кроком проводиться іiі очищення.

Таблиця 9

Очищена матриця кореляцій культурно-освітньої моделі

\begin{tabular}{|c|c|c|c|}
\hline Показники & X13 & X14 & X15 \\
\hline X13 & 1 & & \\
\hline X14 & 0 & 1 & \\
\hline X15 & 0 & 0,9835 & 1 \\
\hline
\end{tabular}

Професіоналізм педагога: теоретичні й методичні аспекти. - Вип. 12. - Слов'янськ, 2020. 
Є щільний позитивний зв'язок між рівнем інвестицій компаній у навчання персоналу й автономією навчальних закладів. Зростання величини одного показника позитивно позначається на іншому.

Далі перевіримо показники на мінливість і представимо результати в табл. 10.

Таблиця 10

Мінливість показників економічної моделі

\begin{tabular}{|l|c|c|c|}
\hline & $\mathrm{X} 13$ & $\mathrm{X} 14$ & $\mathrm{X} 15$ \\
\hline Коефіцієнт варіації & $9,67 \%$ & $52,08 \%$ & $7,65 \%$ \\
\hline
\end{tabular}

Зафіксована значна мінливість показника «рівень інвестицій компаній в навчання персоналу». Середньорічний темп зростання рівня інвестицій компаній у навчання персоналу становить 1,23.

Для того щоб провести інтегральну оцінку, потрібно привести всі дані до одного виміру. Тому виникає потреба в нормалізації даних. Обумовлено це характером використовуваних показників, бо вони істотно відрізняються в абсолютних значеннях (деякі показники є якісними, а деякі кількісними або деякі показники вимірюються в тисячах, а інші - в сотнях). Нормалізація даних дозволяє привести всі чисельні значення використовуваних змінних до однієї одиниці виміру так, що дає можливість об'єднати їх в одну модель.

Наразі автори проводять нормалізацію даних після визначення середньоквадратичного відхилення кожного показника за допомогою описової статистики. Нормалізація здійснюється шляхом ділення значення статистичного показника на середньоквадратичне відхилення досліджуваної

групи.

$$
x_{i}^{*}=\frac{x_{i}}{\sigma_{x i}}
$$

де $x_{i}^{*}$ - нормалізований показник;

$x_{i}$ - значення показника в групі;

$\sigma_{x i}$ - середньоквадратичне відхилення.

Тепер проводиться інтегральна оцінка, яку буде здійснено спочатку окремо за трьома моделями.

Методика розрахунку передбачає розрахунок синтетичного показника, шляхом суми множень значення i-го члена показника і ваги i-го члена показника.

$$
C_{i}=\sum_{i=1}^{k} x_{i} \cdot v_{i}
$$


де $x_{i}$ - значення $i$-го члена показника;

$v_{i}$ - вага $i$-го члена показника;

$k$ - число показників.

Інтегральний показник буде визначений за такою формулою:

$$
I=\sum_{i=1}^{n} C_{i} \cdot w_{i}
$$

де $C_{i}$ - синтетичний показник $i$-ї складової,

$w_{i}$ - вага $i$-ї складової,

$n$ - число складових.

Таблиця 11

Проміжні результати розрахунків синтетичного показника моделі оцінки потенціалу впровадження дуальної освіти

\begin{tabular}{|c|c|c|c|c|c|c|}
\hline Показники & 2014 & 2015 & 2016 & 2017 & 2018 & Вага \\
\hline \multicolumn{7}{|c|}{ Економічна складова } \\
\hline Рівень інвестиційної привабливості & 0,190 & 0,257 & 0,195 & 0,100 & 0,190 & 0,19 \\
\hline $\begin{array}{l}\text { Середній рівень зарплат } \\
\text { професійному секторі }\end{array}$ & 0,216 & 0,159 & 0,189 & 0,103 & 0,180 & 0,18 \\
\hline Рівень безробіття серед молоді & 0,213 & 0,180 & 0,194 & 0,100 & 0,180 & 0,15 \\
\hline Рівень зайнятості молоді & 0,209 & 0,233 & 0,150 & 0,130 & 0,185 & 0,1 \\
\hline $\begin{array}{lll}\text { Податкове } & \text { навантаження } & \text { на } \\
\text { підприємства } & & \\
\end{array}$ & 0,205 & 0,294 & 0,151 & 0,129 & 0,200 & 0,18 \\
\hline Рівень тіньового ринку праці & 0,190 & 0,257 & 0,195 & 0,100 & 0,190 & 0,1 \\
\hline Рівень конкуренції в країні & 0,216 & 0,159 & 0,189 & 0,103 & 0,180 & 0,1 \\
\hline Синтетичний показник & $\mathbf{0 , 2 1 3}$ & $\mathbf{0 , 1 8 0}$ & $\mathbf{0 , 1 9 4}$ & 0,100 & $\mathbf{0 , 1 8 0}$ & \\
\hline \multicolumn{7}{|c|}{ Політична складова } \\
\hline Частка витрат ВВП на освіту & 0,350 & 0,350 & 0,350 & 0,350 & 0,350 & 0,35 \\
\hline Рівень впливу профспілок & 0,767 & 0,926 & 1,014 & 1,019 & 0,896 & 0,2 \\
\hline $\begin{array}{l}\text { Рівень впливу організацій } \\
\text { роботодавців }\end{array}$ & 1,125 & 1,278 & 1,495 & 1,500 & 1,343 & 0,15 \\
\hline Рівень корупції & 0,947 & 0,961 & 0,916 & 0,981 & 0,716 & 0,15 \\
\hline Рівень плинності кадрів & 0,425 & 0,500 & 0,420 & 0,538 & 0,515 & 0,15 \\
\hline Синтетичний показник & 3,613 & 4,015 & 4,194 & 4,388 & 3,820 & \\
\hline \multicolumn{7}{|c|}{ Культурно-освітня складова } \\
\hline Престиж професійної освіти & 1,135 & 1,021 & 1,082 & 1,000 & 1,266 & 0,4 \\
\hline $\begin{array}{lrr}\text { Рівень інвестицій } & \text { компаній } \\
\text { навчання персоналу } & & \\
\end{array}$ & 1,000 & 1,429 & 2,143 & 2,714 & 4,000 & 0,3 \\
\hline Автономія навчальних закладів & 1,000 & 1,044 & 1,111 & 1,111 & 1,222 & 0,3 \\
\hline Синтетичний показник & 3,135 & 3,494 & 4,336 & 4,825 & 6,488 & \\
\hline
\end{tabular}

Професіоналізм педагога: теоретичні й методичні аспекти. - Вип. 12. - Слов'янськ, 2020. 
На підставі розрахунку синтетичних показників за складовими оцінки потенціалу впровадження дуального навчання можна провести розрахунок інтегрального показника.

Таблиця 12

Інтегральний показник потенціалу впровадження дуальної освіти

\begin{tabular}{|l|c|c|c|c|c|l|}
\hline \multicolumn{1}{|c|}{ Складові } & $\mathbf{2 0 1 4}$ & $\mathbf{2 0 1 5}$ & $\mathbf{2 0 1 6}$ & $\mathbf{2 0 1 7}$ & $\mathbf{2 0 1 8}$ & Вага \\
\hline Економічна складова & 0,472 & 0,432 & 0,442 & 0,446 & 0,472 & 0,4 \\
\hline Політична складова & 1,084 & 1,204 & 1,258 & 1,316 & 1,146 & 0,3 \\
\hline Культурно-освітня складова & 0,940 & 1,048 & 1,301 & 1,448 & 1,946 & 0,3 \\
\hline Інтегральний показник & $\mathbf{2 , 4 9 6}$ & $\mathbf{2 , 6 8 5}$ & $\mathbf{3 , 0 0 1}$ & $\mathbf{3 , 2 1 0}$ & $\mathbf{3 , 5 6 4}$ & \\
\hline
\end{tabular}

За результатами розрахунків простежується динаміка до зростання. Це свідчить про зростання потенціалу впровадження дуального навчання в Україні. Для підтвердження думки про своєчасність і актуальність Упровадження дуального навчання необхідно провести додаткове дослідження по галузях господарювання.

Висновки. Визначено фактори впливу на впровадження дуального навчання (економічні, політичні та культурно-освітні). За кожним фактором зафіксовані показники, а саме: рівень інвестиційної привабливості; середній рівень зарплат у професійному секторі; рівень безробіття серед молоді; рівень зайнятості молоді; податкове навантаження на компанії; рівень тіньового ринку праці; рівень конкуренції в країні; частка витрат ВВП на освіту; рівень впливу профспілок; рівень впливу організацій роботодавців; рівень корупції; рівень плинності кадрів; престиж професійної освіти; рівень інвестицій компаній у навчання персоналу; автономія навчальних закладів.

Також були визначені кореляційні взаємовпливи між показниками факторів впливу впровадження дуального навчання. Щільний негативний зв'язок зафіксований між рівнем зайнятості молоді та рівнем безробіття серед молоді: зростання одного чинника впливає на зниження іншого. А зниження показника рівня тіньового ринку праці впливає на підвищення рівня зайнятості молоді. Щільний позитивний зв'язок зафіксований між рівнем впливу організацій роботодавців і рівнем впливу профспілок: зростання величини одного показника позитивно позначається на іншому. Також щільний позитивний зв'язок зафіксовано між рівнем інвестицій компаній у навчання персоналу й автономією навчальних закладів: зростання величини одного показника позитивно позначається на іншому.

Перспективи подальших досліджень убачаємо в оцінці впровадження потенціалу дуального навчання за галузями економіки окремо. Це дасть 
можливість більш економічно й обгрунтовано реалізувати окреслений перспективний вектор.

\section{СПИСОК ВИКОРИСТАНИХ ДЖЕРЕЛ}

1. Вчитися на роботі: як працюватиме дуальна освіта в Україні. (б.д.). Взято 3 https://uain.press/articles/vchytysya-na-roboti-yak-zapratsyuye-dualna-osvita-v-ukrayini-943921

2. Дуальна освіта - партнерство вишів і бізнесу. (б.д.). Взято 3 https://dt.ua/EDUCATION/dualna-osvita-partnerstvo-vishiv-i-biznesu-295022_.html

3. Дуальна освіта. (б.д.). Взято 3 http://www.nusta.edu.ua/дуальна-освіта-3/

4. Левченко, Я. С. (2020). Дуальное обучение для Украины: факторы влияния и потенциальные возможности его имплементации. Herald pedagogiki. Nauka i Praktyka, 52, $14-18$.

5. Левченко, Я. С., Волинец, Л.Н. (2019). Проблемы высшей школы глазами студента. Взято $3 \mathrm{http}: / /$ конференция.com.ua/files/91_s.pdf

6. Левченко, Я. С., Шершенюк, О. М. (2020). Дуальна освіта як складова фінансового забезпечення держави в контексті розвитку державно-приватного партнерства. Herald pedagogiki. Nauka i Praktyka, 53 (Препринт. Herald pedagogiki. Nauka i Praktyka).

7. Офіційний сайт Державної служби статистики України. (б.д.). Взято 3 http://www.ukrstat.gov.ua/

8. BDO international business compass. (2018). Взято 3 https://www.bdoibc.com/index.php?id=35

9. Lechachenko, T. (2019). Analysis of foreign experience of implementation of the dual form of education and accessibility of its implementation in Ukraine. Technology Audit and Production Reserves, 2(47), 31-38. DOI: http://doi.org/10.15587/2312-8372.2019.174529

10. Official site of Eurostat. (б.д.). Взято 3 https://ec.europa.eu/eurostat/data/database

11. Official site of Organisation for Economic Cooperation and Development OECD. (б.д.). Взято 3 https://data.oecd.org

12. PayingTaxes 2018 PwC Global. Взято 3 https://www.pwc.com/gx/en/payingtaxes/pdf/pwc_paying_taxes_2018_full_report.pdf

13. Schwab, K. (2018). WEF Global Competitiveness Report. Взято 3 http://reports.weforum.org/global-competitiveness-report-

2018/competitivenessrankings/\#series=GCI4.C.07.01

14. Transparency International, Corruption perception index. (2018). Взято 3 https://www.transparency.org/cpi2018

\section{ASSESSMENT OF THE POTENTIAL OF DUAL EDUCATION SYSTEM IMPLEMENTATION IN UKRAINE}

\section{Yaroslava Levchenko}

$\mathrm{PhD}$ in Social and Behavioral Sciences, Associate Professor, Associate Professor of Economics and Entrepreneurship Department, Kharkiv National Automobile and Highway University

Kharkiv, Ukraine

ORCID ID 0000-0002-4979-1101

slavalevcenko1984@gmail.com

\section{Olena Shersheniuk}

$\mathrm{PhD}$ of Economic Sciences, Associate Professor, 


\title{
Associate Professor of Economics and Entrepreneurship Department, Kharkiv National Automobile and Highway University Kharkiv, Ukraine ORCID ID 0000-0002-9959-2725 sheralyona@gmail.com
}

\begin{abstract}
This article assesses the potential of introducing a dual education system in Ukraine, which is the purpose of the study. To achieve the designated purpose, the following tasks have been solved: factors of influence on the introduction of dual education and their indicators have been determined; based on the construction of the matrix of correlation relationships, the correlation interactions between the indicators of the influence factors of dual education introduction have been determined. The calculation results have recorded the dynamics of an increase in the integral indicator of the potential for implementing the dual training system between 2014 and 2018. This indicates an increase in the potential for introducing dual education in Ukraine.

The factors of influence on the introduction of dual education - economic, political and cultural-educational ones - have been determined. When calculating the potential of introducing a dual education system, the following indicators are used: level of investment attractiveness, average level of salaries in the professional sector, youth unemployment rate, youth employment rate, tax burden on enterprises, level of shadow labor market, level of competition in the country, the share of GDP spending on education, the level of influence of trade unions, the level of influence of employers organizations, the level of corruption, the level of staff turnover, prestige of vocational education, the level of investment of companies in personnel education, and the autonomy of educational institutions.

The correlation interactions between the indicators of the influence factors of dual education introduction have been also determined. Both close positive and close negative mutual influences have been defined. A dense negative correlation between youth employment and youth unemployment was recorded. A decrease in the level of the shadow labor market affects the increase in youth employment. A strong positive correlation between the level of influence of employers' organizations and the level of influence of trade unions was recorded. Also, a strong positive correlation between the level of investment of companies in personnel training and the autonomy of educational institutions was recorded.
\end{abstract}

Key words: quality of education; dual education system; the potential for introducing dual education; correlation interactions; factors and indicators of influence.

\section{REFERENCES}

1. Learn at work: how dual education in Ukraine will work. (n.d.). Retrieved from https://uain.press/articles/vchytysya-na-roboti-yak-zapratsyuye-dualna-osvita-v-ukrayini-943921

2. Dual education is a partnership of higher education and business. (n.d.). Retrieved from https://dt.ua/EDUCATION/dualna-osvita-partnerstvo-vishiv-i-biznesu-295022_.html

3. Dual education. (n.d.). Retrieved from http://www.nusta.edu.ua/дуальна-освіта-3/

4. Levchenko, Ya. S. (2020). Dual education for Ukraine: factors of influence and potential opportunities for its implementation. Herald pedagogiki. Nauka i Praktyka, 52, 14-18.

5. Levchenko, Ya. S. \& Volinets, L. N. (2019). Problems of higher education through the eyes of a student. Retrieved from http://конференция.com.ua/files/91_s.pdf

6. Levchenko, Ya. S., Shershenyuk, O. M. (2020). Dual education as a component of state financial support in the context of public-private partnership development. Herald pedagogiki. Nauka i Praktyka, 53 (Preprint. Herald pedagogiki. Nauka i Praktyka).

7. Official site of the State Statistics Service of Ukraine. (n.d.). Retrieved from http://www.ukrstat.gov.ua/

() ДВНЗ «Донбаський державний педагогічний університет» 


\section{Я. ЛЕВЧЕНКО, О. ШЕРШЕНЮК}

Оцінка потенціалу впровадження дуальної системи навчання в Україні

8. BDO international business compass. (2018). Retrieved from https://www.bdoibc.com/index.php?id=35

9. Lechachenko, T. (2019). Analysis of foreign experience of implementation of the dual form of education and accessibility of its implementation in Ukraine. Technology Audit and Production Reserves, 2(47), 31-38. DOI: http://doi.org/10.15587/2312-8372.2019.174529

10. Official site of Eurostat. (n.d.). Retrieved from https://ec.europa.eu/eurostat/data/database

11. Official site of Organisation for Economic Cooperation and Development OECD. (n.d.). Retrieved from https://data.oecd.org

12. PayingTaxes 2018 PwC Global. Retrieved from https://www.pwc.com/gx/en/payingtaxes/pdf/pwc_paying_taxes_2018_full_report.pdf

13. Schwab, K. (2018). WEF Global Competitiveness Report. Retrieved from http://reports.weforum.org/global-competitiveness-report-

2018/competitivenessrankings/\#series=GCI4.C.07.01

14. Transparency International. Corruption perception index. (2018). Retrieved from https://www.transparency.org/cpi2018 